\title{
PERFORMA BABI BALI YANG DIPELIHARA DALAM KANDANG DENGAN ALAS KANDANG TANAH, BETON, DAN LITTER (BAPUK)
}

\author{
SURYA KENCANA JAYA, P. G. A ${ }^{1)}$, K. BUDAARSA ${ }^{2)}$ DAN I G. MAHARDIKA ${ }^{2)}$ \\ 1)Program Studi Magister Ilmu Peternakan \\ 2)Fakultas Peternakan Universitas Udayana \\ e-mail:pandekencana@yahoo.com
}

\begin{abstract}
ABSTRAK
Penelitian bertujuan untuk mengetahui performa babi bali yang dipelihara dalam kandang dengan alas kandang yang berbeda. Penelitian dilakukan selama 3 bulan mulai bulan Agustus sampai November. Penelitian menggunakan babi bali dengan berat 12-13 kg. Rancangan percobaan yang digunakan adalah rancangan acak lengkap (RAL). Perlakuan yang diberikan yaitu babi bali yang dipelihara dalam kandang dengan menggunakan alas tanah (A) sebagai kontrol, kandang dengan menggunakan alas beton (B), kandang dengan menggunakan alas litter (bapuk) (C). Peubah yang diamati pada penelitian adalah performa produksi, kecernaan nutrien, iklim mikro, analisis ekonomi, dan kepadatan lalat pada kandang. Hasil penelitian menunjukkan bahwa berat badan akhir, pertambahan berat badan, konsumsi ransum, kecernaan bahan kering, kecernaan bahan organik, kecernaan lemak, kecernaan serat kasar, kecernaan abu, dan iklim mikro pada kandang menunjukkan hasil yang sama $(\mathrm{P}>0,05)$. Feed convertion ratio (FCR) dan kecernaan protein menunjukkan hasil yang lebih baik pada alas beton dan bapuk $(\mathrm{P}<0,05)$. Kesimpulan dalam penelitian ini adalah performa babi bali yang dipelihara dalam kandang dengan menggunakan alas yang berbeda tidak memberikan pengaruh. Biaya produksi paling efisien dan hasil produksi paling tinggi didapatkan pada kandang babi bali yang dipelihara dengan menggunakan alas tanah.
\end{abstract}

Kata kunci: babi bali, kandang, performa, analisis ekonomi

\section{PERFORMANCE OF BALI PIGS WERE BRED IN THE PIGSTIES WITH SOIL, CONCRETE, AND LITTER BASES (BAPUK)}

\begin{abstract}
The study aimed to determine the performance of bali pigs which were bred in pigsties with different bases. The study was conducted for 3 months starting from August to November. The research used bali pigs weighing 12-13 $\mathrm{kg}$. The experimental design used was a completely randomized design (CRD). The treatments given were bali pigs which were bred on a base using a soil base (A) as a control, pigsty using a concrete base (B), and pigsty using a litter base (bapuk) (C). The results of the study obtained production performance, nutrient digestibility, microclimate, economic analysis, and density of flies in the pigsties. Variables observed were the final body weight, weight gain, feed consumption, dry matter digestibility, organic matter digestibility, fat digestibility, crude fiber digestibility, ash digestibility, and micro climate in the pigsty showed similar results $(\mathrm{P}>0,05)$. Feed Conversion Ratio (FCR) and protein digestibility showed better results using a concrete and litter base $(\mathrm{P}<0,05)$. The conclusion in this study is that the performance of bali pigs which were kept in pigsties using different bases did not give any effect. The most efficient production cost and the highest production yield were found in bali pigsties that were bred using soil bases.
\end{abstract}

Keywords: bali pigs, pigsty, performance, economic analysis

\section{PENDAHULUAN}

Babi bali merupakan plasma nutfah yang perlu dilestarikan karena populasinya dari tahun ke tahun terus mengalami penurunan. Populasi babi bali turun tiap tahunnya dari 272.528 ekor pada tahun 2012, menjadi 215.321ekor pada tahun 2015, mengalami penurunan 20,97\% (Badan Statistik Provinsi Bali, 2015). Hal ini akibat dari tidak seimbangnya antara laju pemotongan dengan laju produksi anak.

Selama ini babi bali masih dipelihara secara tradisional dan sistem perkandangan yang belum 
memadai serta makanan yang diberikan secara kuantitas dan kualitas sangat rendah. Pemeliharaan babi bali yang demikian ini oleh masyarakat di Bali disebut dengan istilah tatakan banyu. Artinya, babi yang dipelihara hanya sekedar penampung banyu atau segala limbah yang dihasilkan selama proses memasak di dapur kemudian diberikan kepada ternak babi agar limbah tersebut tidak terbuang, maka dipeliharalah babi satu sampai dua ekor dalam satu rumah tangga (Budaarsa, 2014).

Secara genetik babi bali memiliki pertumbuhan yang lebih lambat dibandingkan dengan babi ras. Diperlukan waktu 12 bulan untuk mencapai berat badan $80 \mathrm{~kg}$, sedangkan babi ras hanya 5-6 bulan. Tetapi babi bali memiliki kelebihan yaitu dapat bertahan pada kondisi ekstrim, lebih hemat penggunaan air, dan masih mampu bertahan hidup dengan kualitas pakan yang rendah, sehingga sangat cocok dipelihara di daerah yang kering (Budaarsa, 2012).

Pemeliaharaan babi bali dengan cara intensif dengan manajemen yang baik mulai dari perkandangan, makanan serta perawatannya memang mampu meningkatkan produksi. Menurut Budaarsa et al. (2016) peternak kecil yang kurang mampu tidak bisa menerapkannya oleh karena itu perlu dibentuk sebuah sistem pemeliharaan yang lebih sederhana sehingga memungkin diterapkan oleh peternak kecil di pedesaan. Selain itu peternakan babi sering mendapat keluhan karena baunya yang menyengat dan mengundang banyak lalat.

Limbah peternakan merupakan semua yang berasal dari ternak atau sebuah peternakan dalam bentuk cair maupun padat yang belum termanfaatkan dengan baik, termasuk di dalamnya seperti kotoran (feses) dan air kencing (urin) yang dihasilkan oleh ternak (Sihombing, 2006). Limbah yang paling banyak dihasilkan dalam usaha peternakan adalah kotoran ternak, selain limbah sisa pakan itu sendiri. Maka dari itu untuk mengurangi dampak pencemaran lingkungan yang diakibatkan oleh kotoran ternak (feses) maka salah satu cara yang dapat dilakukan adalah dengan cara mengolah kotoran tersebut menjadi pupuk organik.

\section{MATERI DAN METODE PENELITIAN}

\section{Waktu dan Lokasi Penelitian}

Penelitian ini dilaksanakan di Banjar Pangkung Gayung, Desa Baler Bale Agung, Kecamatan Negara, Kabupaten Jembrana selama 3 bulan.

\section{Babi Bali}

Babi yang digunakan dalam penelitian ini adalah babi bali jantan lepas sapih dengan berat 12-13 kg sebanyak 15 ekor yang dibeli dari peternak babi bali di Banjar Pegending, Desa Dalung, Kecamatan Kuta Utara, Badung.

\section{Kandang dan Perlengkapannya}

Kandang yang digunakan dalam penelitian ini terdiri atas 3 kandang yaitu kandang dengan menggunakan alas tanah, beton, dan litter (Bapuk) dengan ukuran kandang panjang $\times$ lebar $=4 \mathrm{~m} \times 3 \mathrm{~m}$ dengan menggunakan atap asbes serta dilengkapi dengan tempat pakan dan tempat air minum.

\section{Ransum Penelitian}

Ransum yang digunakan dalam penelitian ini disusun dari bahan-bahan antara lain: jagung kuning, pollard, ransum komersial 551, dan mineral. Pemberian ransum dilakukan dua kali sehari yaitu pada pagi hari dan sore hari yang diberikan secara ad libitum.

\section{Rancangan Percobaan}

Penelitian ini menggunakan metode percobaan dengan model rancangan acak lengkap (RAL) dengan menggunakan tiga perlakuan dan lima ulangan dengan menggunakan materi babi bali dengan berat antara 12-13 kg. Perlakuan yang digunakan dibagi menjadi tiga kandang yaitu kandang dengan menggunakan alas tanah sebagai kontrol (perlakuan A); kandang dengan menggunakan alas beton (perlakuan B); kandang dengan menggunakan alas litter atau kandang Bapuk (perlakuan C). Setiap perlakuan diulang sebanyak 5 kali, sehingga total jumlah babi yang digunakan sebanyak 15 ekor.

\section{Peubah yang Diamati}

Peubah yang diamati pada penelitian ini yaitu berat badan awal, berat badan akhir, pertambahan berat badan, konsumsi ransum, feed convertion ratio (FCR), koefisien cerna ransum, iklim mikro, analisis ekonomi, dan kepadatan lalat dalam kandang.

Berat badan awal didapatkan dengan cara melakukan penimbangan pada awal penelitian sebelum babi diberikan perlakuan. Berat akhir diperoleh dengan cara melakukan penimbangan pada akhir penelitian. Pertambahan berat badan diperoleh dengan cara mengurangi berat badan akhir dengan berat badan awal penelitian. Konsumsi ransum dihitung setiap hari dengan mengurangi jumlah ransum yang diberkan dengan sisa ransum pada hari tersebut. Total konsumsi ransum diperoleh dengan cara menjumlahkan konsumsi ransum setiap hari selama penelitian. FCR dihitung dengan perbandingan antara jumlah ransum yang dikonsumsi dengan pertambahan bobot badan selama penelitian. FCR merupakan tolok ukur untuk menilai tingkat efisiensi dalam penggunaan ransum.

$$
\mathrm{FCR}=\frac{\text { Total konsumsi ransum) }}{\text { pertambahan bobot badan }}
$$


Kecernaan dihitung dengan metode koleksi total yaitu dilakukan dengan mengumpulkan hasil dari input maupun output dari ternak tersebut. Koleksi total diakukan dengan cara mengumpulkan sisa pakan dan feses selama 3 hari, koefisien cerna bahan kering dihitung dengan menggunakan rumus:

$$
\text { Konsumsi }=\frac{\text { Konsumsi Bahan Kering }- \text { Feses }}{\text { Konsumsi Bahan Kering }} \times 100 \%
$$

Pengukuran variabel iklim mikro kandang dilakukan pada periode awal percobaan, pertengahan, dan akhir penelitian, masing-masing selama tiga hari. Dalam satu hari dilakukan tiga kali pengukuran yaitu 07.00 Wita, 12.00 Wita, dan 15.00 Wita. Analisis ekonomi merupakan sebuah studi dengan tujuan untuk mengetahui dan menilai suatu kegiatan dapat dikatakan layak atau tidaknya berdasarkan dari aspek finansial. Menurut Soekartawi (2006), data dianalisis untuk menentukan pendapatan bersih (net farm income), revenue cost ratio ( $\mathrm{R} /$ Cratio), titik impas harga, dan titik impas produksi. Pendapatan bersih merupakan selisih antara penerimaan dengan semua biaya yang dikeluarkan, yang ditentukan dengan rumus:

$$
\text { Pendapatan = TR-TC }
$$

Kepadatan lalat dalam kandang diukur dengan cara masing-masing kandang dipasangkan perangkap lalat untuk mengamati berapa jumlah lalat yang menempel pada masing-masing perlakuan.

\section{Analisis Data}

Data hasil penelitian dianalisis dengan sidik ragam. Jika diperoleh hasil yang berbeda nyata $(\mathrm{P}<0,05)$ dilanjutkan dengan Uji Jarak Berganda dari Duncan (Duncan's Multiple Range Test) (Steel dan Torrie, 1995). Pengolahan data menggunakan program aplikasi statistik SPSS 16.

\section{HASIL DAN PEMBAHASAN}

\section{Performa Babi Bali}

Hasil penelitian menunjukkan bahwa konsumsi ransum babi bali yang dipelihara dalam kandang dengan menggunakan alas tanah (perlakuan A) yaitu 107,95 $\mathrm{kg} /$ ekor (Tabel 1). Sedangkan pada perlakuan B dan C yaitu 2,03\% dan 3,23\% lebih rendah dibandingkan dengan perlakuan A dan secara stastistik berbeda tidak nyata $(\mathrm{P}>0,05)$. Hal ini karena kandungan nutrien yang terkandung dalam ransum yang diberikan pada semua perlakuan adalah sama, sehingga mengakibatkan jumlah ransum yang dikonsumsi sama pula. Budaarsa et al. (2016) menyatakan kandungan energi ransum sangat berpengaruh terhadap konsumsi, dimana jika kandungan energi ransum rendah maka konsumsi akan meningkat dan sebaliknya apabila energi ransum tinggi konsumsi akan menurun.

Hasil penelitian menunjukkan bahwa pertambahan berat badan (PBB) pada perlakuan A yaitu $24,78 \mathrm{~kg} /$ ekor (Tabel 1), sedangkan pada perlakuan B dan C yaitu $15,25 \%$ dan $11,38 \%$ lebih tinggi dibandingkan dengan perlakuan A namun secara stastistik berbeda tidak nyata $(\mathrm{P}>0,05)$. Hal ini diakibatkan oleh jumlah konsumsi nutrien yang sama, sehingga memberikan pertambahan berat badan dan berat badan akhir yang sama pada semua perlakuan. Lebih lanjut Ariesta et al. (2015) menyatakan berat badan akhir dipengaruhi oleh jumlah pakan yang dikonsumsi dan kandungan nutrien yang terkandung dalam ransum, apabila konsumsi ransum lebih tinggi maka kandungan nutrien juga lebih banyak diserap oleh tubuh sehingga menyebabkan berat badan akhir menjadi lebih tinggi.

Tabel 1. Performa babi bali yang diperlihara dalam kandang dengan menggunakan alas yang berbeda

\begin{tabular}{lcccc}
\hline \multirow{2}{*}{ Variablel } & \multicolumn{3}{c}{ Perlakuan } & \multirow{2}{*}{ SEM } \\
\cline { 2 - 4 } & A & B & C & \\
\hline Berat badan awal (kg) & $13,02^{\mathrm{a} 1)}$ & $13,04^{\mathrm{a}}$ & $13,00^{\mathrm{a}}$ & 0.91 \\
Berat badan akhir (kg) & $37,80^{\mathrm{a}}$ & $41,62^{\mathrm{a}}$ & $40,61^{\mathrm{a}}$ & 2.3 \\
Pertambahan berat badan (kg) & $24,78^{\mathrm{a}}$ & $28,56^{\mathrm{a}}$ & $27,60^{\mathrm{a}}$ & 2.2 \\
Kosumsi ransum (kg) & $107,95^{\mathrm{a}}$ & $105,76^{\mathrm{a}}$ & $104,46^{\mathrm{a}}$ & 6.9 \\
Konsumsi ransum/ekor/hari (kg/h) & $1,28^{\mathrm{a}}$ & $1,26^{\mathrm{a}}$ & $1,24^{\mathrm{a}}$ & 0.1 \\
FCR & $4,35^{\mathrm{b}}$ & $3,70^{\mathrm{a}}$ & $3,78^{\mathrm{a}}$ & 0.1 \\
\hline
\end{tabular}

Keterangan

1) Superkrip yang sama pada baris yang sama menunjukkan perbedaan yang tidak nyata $(P>0,05)$ dan superkrip yang berbeda pada baris yang sama menunjukkan perbedaan yang nyata $(P<0,05)$

Hasil penelitian menunjukkan bahwa konversi ransum pada perlakuan Ayaitu 4,35 (Tabel 1), sedangkan pada perlakuan B dan C yaitu 3,72 dan 3,83 lebih rendah dibandingkan dengan perlakuan A dan secara stastistik berbeda nyata $(\mathrm{P}<0,05)$. Hal ini diduga akibat tingkat kenyamanan babi pada perlakuan B dan C lebih baik dibandingkan dengan perlakuan A. Kenyamanan ternak dipengaruhi oleh beberapa faktor diantaranya sistem perkandangan yang baik, temperatur lingkungan, serta tempat pakan dan minum yang selalu bersih sehingga dapat menyebabkan kesehatan ternak terjaga dan meminimalisir tingkat stress terhadap ternak (Faiq et al., 2013).

\section{Kecernaan Bahan Pakan}

Hasil penelitian menunjukkan bahwa koefisien cerna bahan kering dari perlakuan A adalah 69,46\% (Tabel 2). Koefisien cerna bahan kering pada perlakuan B dan C lebih tinggi $0,58 \%$ dan 1,43\% dibandingkan dengan perlakuan A, secara statistik menunjukkan berbeda tidak nyata $(\mathrm{P}>0,05)$. Hal ini dipengaruhi oleh tingkat konsumsi dan kandungan nutrien yang terkandung 
dalam ransum pada semua perlakuan adalah sama (Tabel 5.1), sehingga menyebabkan koefisien cerna bahan kering sama pada semua perlakuan. Kecernaan bahan kering dipengaruhi oleh beberapa faktor diantaranya: cara pemberian pakan, perlakuan pada pakan, umur ternak, bangsa, dan bobot hidup ternak yang digunakan dalam penelitian. Hal ini sejalan dengan Lubis (1992) konsumsi bahan kering dipengaruhi oleh 1) Faktor pakan, meliputi palatabilitas dan daya cerna 2) Faktor yang meliputi bangsa, jenis kelamin, umur dan kondisi kesehatan ternak.

Koefisien cerna bahan organik dari perlakuan A adalah 69,90\% (Tabel 2). Koefisien cerna bahan organik dari perlakuan $\mathrm{B}$ dan $\mathrm{C}$ lebih rendah dibandingkan dengan perlakuan A yaitu masing-masing 3,28\% dan 2,39\% dan secara statistik menunjukkan berbeda tidak nyata $(\mathrm{P}>0,05)$. Bahan organik merupakan bagian terbesar dari nutrien pakan ternak dan terbesar yang dibutuhkan oleh ternak. Tinggi rendahnya bahan organik akan disebabkan oleh banyak atau sedikit jumlah konsumsi bahan kering. Hal ini dipengaruhi oleh sebagian besar komponen bahan kering terdiri dari komponen bahan organik, perbedaannya dapat dilihat dari kandungan abu (Murni dan Okrisandi, 2012).

Tabel 2. Koefisien cerna bahan pakan dan energi tercerna ransum pada babi bali yang diperlihara dalam kandang dengan menggunakan alas yang berbeda

\begin{tabular}{lcccc}
\hline \multirow{2}{*}{ Variablel } & \multicolumn{3}{c}{ Perlakuan } & \multirow{2}{*}{ SEM } \\
\cline { 2 - 4 } & $\mathrm{A}$ & $\mathrm{B}$ & $\mathrm{C}$ & \\
\hline Koefisien cerna bahan kering (\%) & $69,46^{\mathrm{a} 1)}$ & $69,86^{\mathrm{a}}$ & $70,45^{\mathrm{a}}$ & 0.4 \\
Koefisien cerna bahan organik (\%) & $69,90^{\mathrm{a}}$ & $67,61^{\mathrm{a}}$ & $68,23^{\mathrm{a}}$ & 1.3 \\
Koefisien cerna protein (\%) & $75,74^{\mathrm{a}}$ & $74,07^{\mathrm{b}}$ & $76,90^{\mathrm{c}}$ & 0.6 \\
Koefisien cerna lemak (\%) & $74,13^{\mathrm{a}}$ & $73,38^{\mathrm{a}}$ & $73,90^{\mathrm{a}}$ & 0.6 \\
Koefisien cerna serat kasar (\%) & $32,69^{\mathrm{a}}$ & $31,04^{\mathrm{a}}$ & $31,76^{\mathrm{a}}$ & 1.7 \\
Koefisien cerna abu (\%) & $70,70^{\mathrm{a}}$ & $70,35^{\mathrm{a}}$ & $70,25^{\mathrm{a}}$ & 0.4 \\
Energi tercerna (Kkal/kg) & $3675,64^{\mathrm{a}}$ & $3457,64^{\mathrm{a}}$ & $3651,77^{\mathrm{a}}$ & 253.5 \\
\hline
\end{tabular}

Keterangan

1) Superkrip yang sama pada baris yang sama menunjukan perbedaan yang tidak nyata $(P>0,05)$ dan superkrip yang berbeda pada baris yang sama menunjukan perbedaan yang nyata $(P<0,05)$

Koefisien cerna protein kasar dari perlakuan A adalah $75.74 \%$ (Tabel 2). Koefisien cerna protein kasar dari perlakuan B lebih rendah 2,21\% dari perlakuan A, sedangkan perlakuan Clebih tinggi 1,53\% dari perlakuan A namun secara statistik menunjukkan berbeda nyata $(\mathrm{P}<0,05)$. Hal ini disebabkan oleh jumlah konsumsi dan kualitas protein yang terkandung pada ransum sama untuk semua perlakuan. Kandungan protein kasar sejalan dengan berat kering suatu pakan, apabila berat kering suatu pakan tinggi, maka protein dari suatu bahan pakan akan tinggi pula. Tillman et al. (1998) menyatakan bahwa tinggi rendahnya suatu kecernaan ransum tergantung pada kualitas dan banyaknya kandungan protein yang terdapat pada ransum, serta berapa banyak protein yang masuk dalam saluran pencernaan.

Koefisien cerna lemak kasar dari perlakuan A adalah 74,13\% (Tabel 2). Koefisien cerna lemak kasar perlakuan $\mathrm{B}$ dan $\mathrm{C}$ lebih rendah dari perlakuan A masing-masing $1,01 \%$ dan $0,31 \%$ dan secara statistik menunjukkan berbeda tidak nyata $(\mathrm{P}>0,05)$. Hal ini disebabkan nilai koefisien cerna bahan organik menunjukkan hasil yang sama pada semua perlakuan. Suprapto et al. (2013) menyatakan bahwa salah satu komponen bahan organik yang terkandung dalam ransum adalah lemak kasar, sehingga meningkatnya kecernaan bahan organik akan berbanding lurus dengan kecernaan lemak kasarnya.

Koefisien cerna serat kasar dari perlakuan A adalah 32,69\% (Tabel 2). Koefisien cerna serat kasar pada perlakuan B dan C lebih rendah dari pada perlakuan A masing-masing 5,05\% dan 2,85\% dan secara statistik menunjukkan berbeda tidak nyata $(\mathrm{P}>0,05)$. Tingkat konsumsi dipengaruhi oleh kandungan serat kasar yang terdapat dalam ransum, hal ini disebabkan serat kasar akan menghambat pertambahan berat badan sehingga mengakibatkan penggunaan makanan menjadi tidak efisien. Jumlah serat kasar yang semakin tinggi dalam ransum dapat menurunkan daya cerna makanan, sehingga walaupun jumlah konsumsi tinggi tetapi pertambahan berat badan relatif rendah dan menyebabkan tidak efisiennya penggunaan makanan oleh ternak (Sihombing, 2006).

Koefisien cerna abu dari perlakuan A adalah 70,70\% (Tabel 2). Koefisien cerna abu pada perlakuan B dan $\mathrm{C}$ lebih rendah dari pada perlakuan A masing-masing 0,50\% dan 0,64\% dan secara statistik menunjukkan berbeda tidak nyata $(\mathrm{P}>0,05)$. Kadar abu dipengaruhi oleh beberapa faktor diantaranya jenis bahan, cara pengabuan, waktu, dan suhu yang digunakan saat pengeringan. Winarno (1992) menyatakan bahwa bahan-bahan yang anorganik yang tidak terbakar dalam proses pengabuan digunakan sebagai acuan kadar abu dari suatu bahan pakan. Berdasarkan hasil penelitian menunjukkan bahwa kecernaan abu pada perlakuan A secara statistik memiliki hasil yang paling tinggi dibandingkan dengan perlakuan lainnya.

Energi tercerna dari perlakuan A adalah 3.675,64 $\mathrm{Kkal} / \mathrm{kg}$ (Tabel 2). Energi tercerna pada perlakuan $\mathrm{B}$ dan $\mathrm{C}$ lebih rendah dari pada perlakuan A yaitu 5,93\% dan $0,65 \%$ dan secara statistik berbeda nyata $(\mathrm{P}>0,05)$. Hal ini dipengaruhi oleh kandungan energi yang terkandung dalam ransum, konsumsi pakan, serta kecernaan bahan organik pada semua perlakuan menunjukkan hasil yang sama. Tingkat konsumsi ransum ditentukan oleh kandungan energi yang ada pada pakan ternak, karena ternak akan berhenti makan ketika energi yang diperlukan oleh ternak sudah terpenuhi (Anggorodi, 1994). Hal ini terjadi akibat 
sintesis lemak dari karbohidrat yang terdapat dalam ransum. Mahardika (2015) menyatakan bahwa energi yang diperoleh hewan dari pakan yang dikonsumsi hanya sebagian kecil yang dapat dimanfaatkan oleh tubuh ternak. Energi yang tersimpan dalam tubuh ternak dapat berupa karbohidrat, protein, dan dalam bentuk lemak.

\section{Iklim Mikro}

Hasil penelitian menunjukan bahwa temperatur udara dalam kandang pada perlakuan A sebesar $27,67{ }^{\circ} \mathrm{C}$, sedangkan pada kandang perlakuan B lebih tinggi yaitu 4,16\% dan pada perlakuan $C$ yaitu sebesar $1,12 \%$ namun secara statistik menunjukkan berbeda tidak nyata $(\mathrm{P}>0,05)$. Suhu optimum kandang babi pada fase grower yaitu 15 ${ }^{\circ}-25^{\circ} \mathrm{C}$ dipengaruhi oleh cahaya matahari, sirkulasi udara, posisi kandang, atap kandang, dan alas kandang (Mulyono, 2001). Pada saat kondisi temperatur udara lebih tinggi dari kondisi nyaman ternak, biasanya pelepasan panas yang dilakukan oleh ternak melalui evaporative heat loss dengan cara melakukan pertukaran panas melalui permukaan kulit (sweating) atau melalui pertukaran panas pada sepanjang saluran pernafasan (panting) dan sebagian melalui feses dan urin (McDowell, 1972). Ternak pada umumnya akan mengalami stress pada suhu udara yang tinggi sehingga akan menyebabkan penurunan konsumsi pakan serta penurunan berat badan (Nova, 2008).

Tabel 3. Iklim mikro pada kandang babi bali yang dipelihara dengan menggunakan alas yang berbeda

\begin{tabular}{lcccc}
\hline \multirow{2}{*}{ Variabel } & \multicolumn{3}{c}{ Perlakuan } & SEM \\
\cline { 2 - 4 } & $\mathrm{A}$ & $\mathrm{B}$ & $\mathrm{C}$ & \\
\hline $\begin{array}{l}\text { Temperatur udara dalam } \\
\text { kandang ( }{ }^{\circ} \mathrm{C} \text { ) }\end{array}$ & $27,67^{\mathrm{a} 1)}$ & $28,82^{\mathrm{a}}$ & $27,98^{\mathrm{a}}$ & 0.7 \\
$\begin{array}{l}\text { Kelembaban udara dalam } \\
\text { kandang (\%) }\end{array}$ & $56,18^{\mathrm{a}}$ & $55,28^{\mathrm{a}}$ & $55,01^{\mathrm{a}}$ & 1.1 \\
$\begin{array}{l}\text { Kecepatan udara dalam } \\
\text { kandang (km/jam) }\end{array}$ & $19,78^{\mathrm{a}}$ & $20,67^{\mathrm{a}}$ & $21,51^{\mathrm{a}}$ & 4.3 \\
\hline
\end{tabular}

Keterangan

1) Superkrip yang sama pada baris yang sama menunjukan perbedaan yang tidak nyata $(P>0,05)$ dan superkrip yang berbeda pada baris yang sama menunjukan perbedaan yang nyata $(P<0,05)$

Hasil penelitian menunjukan bahwa kelembaban udara dalam kandang pada perlakuan A sebesar $56,18 \%$, sedangkan pada perlakuan kandang B dan C lebih rendah masing-masing sebesar 1,60\% dan 2,08\% namun secara statistik menunjukkan berbeda tidak nyata $(\mathrm{P}>0,05)$. Kelembaban pada kandang A diduga akibat lantai kandang dengan menggunakan alas tanah sering dalam kondisi basah karena feses yang tercampur dengan urine sehingga memerlukan waktu yang lebih lama untuk tanah menjadi kering kembali. Hal ini sejalan dengan (Kusnadi, 2006) menyatakan bahwa suhu yang tinggi pada kandang akan menyebabkan ternak cenderung lebih banyak mengonsumsi air sehingga hal ini berakibat pada kotoran ternak menjadi lebih lembek. Kelembaban udara dalam kandang dipengaruhi oleh beberapa faktor diantaranya: 1) repirasi, 2) air minum, dan 3) urine dan kotoran ternak (Sugito dan Mira, 2008).

Hasil penelitian menunjukan bahwa kecepatan udara dalam kandang pada perlakuan A sebesar 19,78 $\mathrm{km} / \mathrm{jam}$, sedangkan pada perlakuan kandang B dan C lebih tinggi yaitu sebesar 4,49\% dan $8,74 \%$ namun secara statistik menunjukkan berbeda tidak nyata $(\mathrm{P}>0,05)$. Hal ini mungkin disebabkan oleh tata letak kandang pada perlakuan A yang dikelilingi oleh lebih banyak pohon sehingga hembusan angin ditahan akibat pepohonan yang lebih rapat. Olivia et al., (2015) menyatakan bahwa kandang berjarak terlalu dekat dengan pohon besar berdaun rimbun dapat mengurangi kecepatan angin yang berhembus ke dalam kandang. Performa ternak akan mencapai tahap maksimal apabila memiliki potensi genetik yang unggul, kualitas dan kuantitas ransum yang baik, serta dukungan dari faktor lingkungan yang nyaman (Nuriyasa, 2012).

\section{Kepadatan Lalat pada Kandang}

Hasil penelitian menunjukkan bahwa babi bali yang dipelihara dalam kandang dengan menggunakan alas tanah (perlakuan A) didominasi oleh lalat buah. Hal ini disebabkan akibat kandang dengan menggunakan alas tanah (perlakuan A) memiliki kondisi yang lebih lembab akibat kotoran dan urin bercampur dengan lantai tanah sehingga ammonia yang dihasilkan paling menyengat diantara perlakuan lainnya sehingga mengundang lalat jenis ini untuk hinggap di dalam kandang maupun di sekitar kandang. Lalat buah (Drosophila) memiliki penyebaran yang luas di daerah Asia, Australia, Malaysia, Singapore, dan Afrika (White dan Hancock, 1997). Perkembangan lalat buah dipengaruhi oleh cahaya matahari.

Hasil penelitian menunjukkan bahwa babi bali yang dipelihara dalam kandang dengan menggunakan alas beton (perlakuan B) ditemukan jenis lalat rumah (Musca domestica) dan lalat hijau (Chrysomya megacephala) dengan didominasi oleh lalat hijau. Hal ini disebabkan oleh kotoran yang menumpuk di sekitar kandang dan ceceran pakan yang tersisa serta sampah organik lainnya yang menjadi lokasi yang disukai oleh lalat jenis ini. Chrysomya megacephala atau lalat hijau merupakan lalat dengan ukuran yang tergolong besar dengan ukuran lalat dewasa mencapai $10 \mathrm{~mm}$. Lalat dewasa memiliki warna hijau mengkilap dengan garis hitam pada segmen kedua atau ketiga dari abdomen, serta lalat ini memiliki jenis probosis penjilat (DuPonte dan Larish, 2003).

Hasil penelitian menunjukkan bahwa babi bali yang dipelihara dalam kandang dengan menggunakan alas 


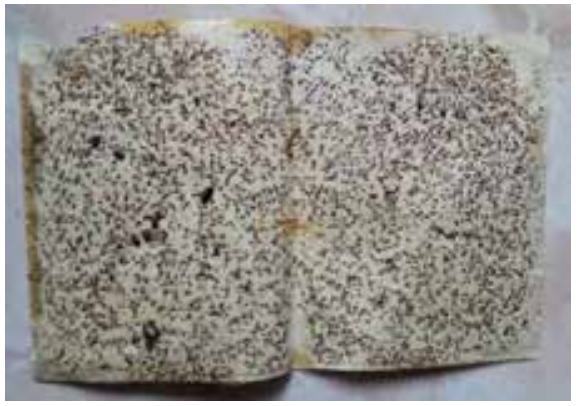

(A)

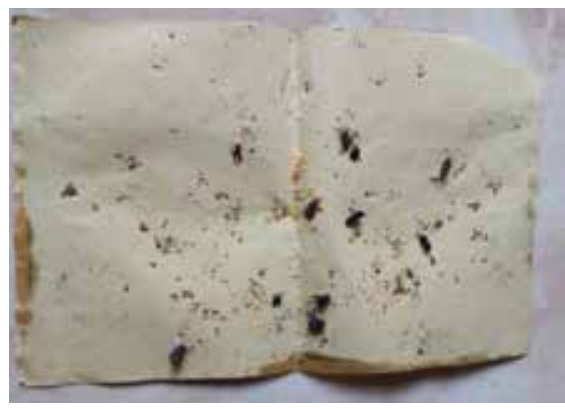

(B)

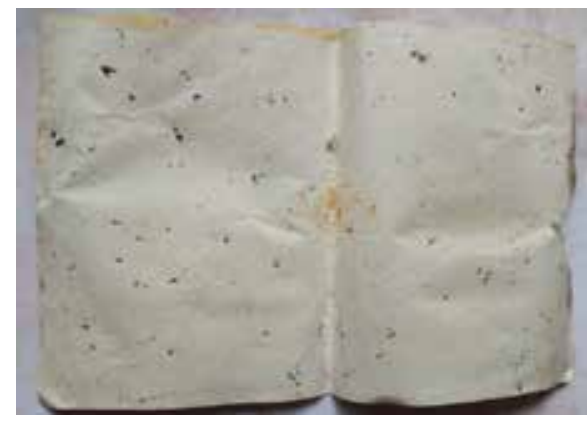

(C)

Gambar 1. Perangkap lalat pada kandang dengan menggunakan alas tanah (A), kandang dengan menggunakan alas beton (B), kandang dengan menggunakan alas litter/bapuk (C)

litter (bapuk) (perlakuan B) ditemukan jenis lalat rumah (Musca domestica) dengan jumlah yang sangat sedikit. Hal ini disebabkan karena feses dan urine bercampur dengan litter yang digunakan sebagai alas kandang sehingga ammonia yang dihasilkan dapat berkurang. Avancini dan Silveira (2004) menyatakan bahwa menurut penelitian yang dilakukan pada kandang ayam petelur di Brazil, lalat (Musca domestica) merupakan lalat dengan urutan pertama jumlah terbanyak yang ditemukan pada peternakan tersebut yang dapat berperan sebagai vektor beberapa jenis penyakit.

Ditinjau dari segi ekonomi menunjukkan, bahwa harga per kilogram ransum adalah $\mathrm{Rp}$ 4.673,08 untuk semua perlakuan. Berdasarkan perhitungan, biaya ransum selama penelitian pada masingmasing perlakuan A, B, dan C yaitu Rp 504.450,00; Rp 494.216,00; dan Rp 488.141,00. Ditinjau dari segi ekonomi, harga ransum babi sama pada semua perlakuan yaitu sebesar Rp.4.673,00. Pertambahan berat badan babi yang mendapatkan perlakuan A, B, dan C secara berturut-turut adalah $0,295 \mathrm{~kg} / \mathrm{h}, 0,340$ $\mathrm{kg} / \mathrm{h}$, dan $0,328 \mathrm{~kg} / \mathrm{h}$. Bila dihitung biaya pakan untuk kenaikan $1 \mathrm{~kg}$ berat badan (PBB), maka perlakuan A adalah Rp.15.840,00 kg/PBB, sedangkan ransum pada perlakuan B, dan C berturut-turut Rp.13.744,00 kg/ PBB, dan Rp.14.246, oo kg/PBB.

Berdasarkan nilai konversi ransum (Tabel 1), pada perlakuan A memiliki rasio konversi ransum paling tinggi yaitu 4,35 kemudian diikuti perlakuan B $(3,72)$, sedangkan nilai konversi ransum pada perlakuan $\mathrm{C}$ $(3,83)$. Berdasarkan harga jual ternak dan biaya total produksi dan pembelian bakalan, maka keuntungan yang diperoleh dari perlakuan $\mathrm{A}, \mathrm{B}$, dan $\mathrm{C}$ masingmasing adalah Rp 3.796.264,oo (A); Rp 3.812.456,oo (B); dan Rp 3.799.221,o0 (C) atau keuntungan per ekor masing-masing adalah $\mathrm{Rp} 540.747,00$ (A); Rp 537.509,00 (B); dan Rp 540.155 (C) Namun, secara teknis dan ekonomis penggunaan ransum yang paling efisien untuk menghasilkan per kilogram berat badan adalah perlakuan $\mathrm{B}$, kemudian $\mathrm{C}$, dan $\mathrm{A}$. Babi bali yang dipelihara dalam kandang dengan menggunakan alas litter (bapuk) dapat memberikan penghasilan tambahan dari hasil penjualan pupuk yaitu sebesar Rp. 360.000,00.

\section{SIMPULAN}

Kesimpulan dalam penelitian ini adalah performa babi bali yang dipelihara dalam kandang dengan menggunakan alas yang berbeda tidak memberikan pengaruh. Biaya produksi paling efisien dan hasil produksi paling tinggi didapatkan pada kandang babi bali yang dipelihara dengan menggunakan alas tanah.

\section{DAFTAR PUSTAKA}

Anggorodi, R. 1994. Ilmu Makanan Ternak Umum. Gramedia, Jakarta

Ariesta, A. H., I. G. Mahardika dan G. A. M. K. Dewi. 2105. Pengaruh level energy dan protein ransum terhadap penampilan ayam buras umur o-10 minggu. Majalah Ilmiah Petrnaka. Fakultas Peternakan. Universitas Udayana. Denpasar.Vol. 8 No. 3 Hal. 89- 94.

Avancini, R. M., Silveira GA. 2000. Age structure and abundance in populations of muscoid flies from a poultry facility in Southeast Brazil. Mem Inst Oswaldo Cruz. 95(2):259-264.

Bali dalam Angka.2015. Badan Pusat Statistik Provinsi Bali. Penerbit BPS Provinsi Bali.

Budaarsa. K. 2012. Babi Guling Bali dari Beternak Kuliner hingga Sesaji. Penerbit Buku Arti.Denpasar.

Budaarsa.K. 2014. Potensi ternak babi dalam menyumbangkan daging di Bali. Makalah disampaikan pada Seminar Nasional Ternak Babi di Fakultas Peternakan Universitas Udayana, 5 Agustus 2014.

Budaarsa.K., A.W. Puger dan I.M. Suasta. 2016. Eksplorasi komposisi pakan babi tradisional babi bali. Majalah Ilmiah Peternakan.19.1: 6-11.

DuPonte M.W. Dan L.B. Larish. 2003. Oriental blow fly [ulasan]. Livestock Man Insect Pests.9:10. 
Faiq, U., N. Iriyanti dan Roesdiyanto. 2013. Penggunaan pakan fungsional dalam ransum terhadap konsumsi pakan dan pertambahan bobot badan ayam broiler. Jurnal Ilmiah Peternakan 1(1):282-288.

Kusnadi, E. 2006. Suplementasi Vitamin C Sebagai Penangkal Cekaman Panas Pada Ayam Broiler.http:// suplementasi.

Lubis, D. A. 1992. Ilmu Makanan Ternak. PT. Pembangunan, Jakarta.

McDowell, R. E. 1972. Improvement of Livestock Production in Warm Climates. W.H. Freeman and Company, San Fransisco.

Mahardika, I G. 2015. Bioenergitika Hewan Tropika. Cetakan I. Penerbit Buku Arti, Bali.

Mulyono, S. 2001. Memelihara Ayam Buras Berorientasi Agribisnis. Penebar Swadaya, Jakarta.

Murni, A. dan Y. Okrisandi. 2012. Pemanfaatan Kulit Buah Kakao yang difermentasi dengan Kapang Phanerochaete chrysosporium sebagai Pengganti Hijauan dalam Ransum Ternak Kambing. Agribisnis dan industri Peternakan, 2(1): 6-10.

Nova, K. 2008. Pengaruh perbedaan presentase pemberian ransum antara siang dan malam hari terhadap performans broiler CP 707. Jurnal Animal Production, Vol. 10(2) halaman 117-121.

Nuriyasa, M. 2012. Respon Biologi serta Pendugaan Kebutuhan Energi dan Protein Ternak Kelinci Lokal (Lepus nigricollis) pada Kondisi Lingkungan Berbeda di Daerah Dataran Rendah Tropis. Disertasi. Program Pasca Sarjana, Universitas Udayana, Denpasar.
Olivia, M., M. Hartono, dan V. Wanniatie. 2015. Pengaruh jenis bahan litter terhadap gambaran darah broiler yang dipelihara di closed house. Jurnal Ilmiah Peternakan Terpadu 3(1): 23-28.

Sihombing, D.T.H. 2006. Ilmu Ternak Babi. Gajahmada Univesity Press.Yoyakarta.

Soeprapto, H., F.M. Suhartati, dan T. Widyastuti. 2013. Kecernaan Serat Kasar Complete Feed Limbah Rami dengan Sumber Protein Berbeda pada Kambing Peranakan Etawa Lepas Sapih. Jurnal Ilmiah Peternakan. Fakultas Peternakan. Universitas Jendral Soedirman. Purwokerto. 1(3) 938-946.

Steel, R. G. D. dan J. H. Torrie. 1995. Prinsip dan Prosedur Statistik. Suatu Pendekatan Biometrik. Terjemahan: B. Sumantri. PT. Gramedia, Jakarta.

Sugito dan D. Mira. 2008. Dampak Cekaman Panas Terhadap Pertambahan Bobot Badan Rasio HeterofilLimfosit dan Suhu Tubuh Ayam Broiler. Universitar Syiah Kuala. Aceh.

Tillman, A. D., H. Hartadi, S. Reksohadiprodjo, S. Prawiro Kusuma, dan S. Lebdosoekoekojo. 1998. Ilmu Makanan Ternak Dasar. Gadjah Mada University Press, Yogyakarta.

White, I. M dan D. L. Hancock. 1997. Cabikey to the Dacini (Diptera: Tephritidae) of the Asian, Pasific, and Australian Regions. Wallingford, UK: CABI.

Winarno, FG. 1992. Kimia Pangan dan Gizi. Gramedia Utama Pustaka. Jakarta. 